\title{
ACE-FTS observation of a young biomass burning plume: first reported measurements of $\mathrm{C}_{2} \mathrm{H}_{4}, \mathrm{C}_{3} \mathrm{H}_{6} \mathrm{O}, \mathrm{H}_{2} \mathrm{CO}$ and $\mathrm{PAN}$ by infrared occultation from space
}

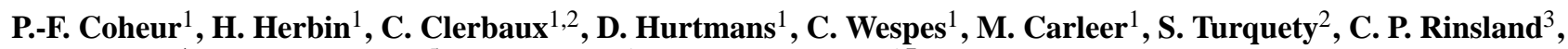 \\ J. Remedios ${ }^{4}$, D. Hauglustaine ${ }^{5}$, C. D. Boone ${ }^{6}$, and P. F. Bernath ${ }^{6,7}$ \\ ${ }^{1}$ Spectroscopie de l'atmosphère, Chimie Quantique et Photophysique, Univ. Libre de Bruxelles (U.L.B.), Brussels, Belgium \\ ${ }^{2}$ Service d'Aéronomie/Institut Pierre-Simon Laplace, CNRS, Université Pierre et Marie Curie-Paris 6, France \\ ${ }^{3}$ NASA Langley Research Center, Mail Stop 401A, Hampton, VA 23681-2199, USA \\ ${ }^{4}$ Earth Observation Science, Space Research Centre, Department of Physics \& Astronomy, University of Leicester, University \\ Road, Leicester, LE1 7RH, UK \\ ${ }^{5}$ Laboratoire des Sciences du Climat et de l'Environnement (LSCE)/Institut Pierre-Simon Laplace, CEA-CNRS, 91191 \\ Gif-sur-Yvette CEDEX, France \\ ${ }^{6}$ Department of Chemistry, University of Waterloo, Waterloo, Ontario, N2L 3G1, Canada \\ ${ }^{7}$ Department of Chemistry, University of York, Heslington, York YO10 5DD, UK
}

Received: 8 May 2007 - Published in Atmos. Chem. Phys. Discuss.: 4 June 2007

Revised: 24 September 2007 - Accepted: 15 October 2007 - Published: 19 October 2007

\begin{abstract}
In the course of our study of the upper tropospheric composition with the infrared Atmospheric Chemistry Experiment - Fourier Transform Spectrometer (ACEFTS), we found an occultation sequence that on 8 October 2005, sampled a remarkable plume near the east coast of Tanzania. Model simulations of the CO distribution in the Southern hemisphere are performed for this period and they suggest that the emissions for this event likely originated from a nearby forest fire, after which the plume was transported from the source region to the upper troposphere. Taking advantage of the very high signal-to-noise ratio of the ACE-FTS spectra over a wide wavenumber range (750$4400 \mathrm{~cm}^{-1}$ ), we present in-depth analyses of the chemical composition of this plume in the middle and upper troposphere, focusing on the measurements of weakly absorbing pollutants. For this specific biomass burning event, we report simultaneous observations of an unprecedented number of organic species. Measurements of $\mathrm{C}_{2} \mathrm{H}_{4}$ (ethene), $\mathrm{C}_{3} \mathrm{H}_{4}$ (propyne), $\mathrm{H}_{2} \mathrm{CO}$ (formaldehyde), $\mathrm{C}_{3} \mathrm{H}_{6} \mathrm{O}$ (acetone) and $\mathrm{CH}_{3} \mathrm{COO}_{2} \mathrm{NO}_{2}$ (peroxyacetylnitrate, abbreviated as PAN) are the first reported detections using infrared occultation spectroscopy from satellites. Based on the lifetime of the emitted species, we discuss the photochemical age of the plume and also report, whenever possible, the enhancement ratios relative to $\mathrm{CO}$.
\end{abstract}

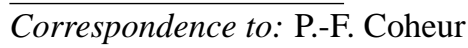

(pfcoheur@ulb.ac.be)

\section{Introduction}

Biomass burning events represent an important source of gases and particles released into the atmosphere (Andreae and Merlet, 2001). A wide variety of species are emitted, including carbon dioxide $\left(\mathrm{CO}_{2}\right)$, carbon monoxide (CO), methane $\left(\mathrm{CH}_{4}\right)$ plus a series of non methane hydrocarbons (NMHCs), oxygenated volatile organic compounds (OVOCs) as well as nitrogen-, sulfur- and halogencontaining species, which are transformed by photochemical processes occurring during the first few hours in the plume (e.g. Jost et al., 2003; Trentmann et al., 2005). These molecules significantly alter the distribution of tropospheric ozone in the Southern Hemisphere and affect the oxidizing capacity of the atmosphere.

For most fires, the plume initially rises no further than the boundary layer. After some time, it can then be transported zonally as well as vertically into the free and eventually the upper troposphere (e.g. Hobbs et al., 2003; Mauzerall et al., 1998). In some cases, however, the species are injected directly into the upper troposphere or even the stratosphere, for example during pyro-convective events (Fromm et al., 2006). There have been numerous studies on the chemical characterization of biomass burning plumes at different stages of their evolution, from so-called fresh to aged plumes. Measurements have been made from the ground or from airplanes using a variety of techniques (e.g. Goode et al., 2000; Hobbs et al., 2003; Yokelson et al., 2003) and modeling of transport and photochemistry has been carried out (Mason et

Published by Copernicus Publications on behalf of the European Geosciences Union. 
al., 2006 and references therein).

The operation of satellite-based instruments in recent years has helped in the analyses of the chemical composition of plumes from large fires, by providing a better spatial and temporal sampling of the burning events. Infrared and UV-visible nadir sounders have provided a wealth of data, enabling the concentration distributions of several important biomass burning products to be derived (e.g. Edwards et al., 2006; Wittrock et al., 2006). However, these measurements lack vertical resolution and the sensitivity to detect weakly absorbing species, which is required for modeling the physical and chemical processes within the plume. Limb emission or solar occultation measurements in the infrared (Bernath et al., 2005) or the microwave (Waters et al., 2006) offer these specific advantages and have been successfully employed recently to probe new organic compounds from space (Dufour et al., 2006; Glatthor et al., 2007; Livesey et al., 2004; Remedios et al., 2006; Rinsland et al., 2006).

This paper is dedicated to the spectral and chemical analysis of a biomass burning plume, which we show, using chemical transport models, to originate from a nearby fire. The emphasis is on the measurement of a series of fire emission products in the upper troposphere, including several species which have never been observed before from space.

\section{Measurements and methods}

\subsection{Measurements}

The ACE-FTS is an infrared Fourier transform spectrometer, operating between 750 and $4400 \mathrm{~cm}^{-1}$ at a spectral resolution of $0.02 \mathrm{~cm}^{-1}( \pm 25 \mathrm{~cm}$ maximum optical path difference) (Bernath et al., 2005). It is the principal instrument onboard the Canadian ACE/SCISAT-1 platform that was launched by NASA into a $74^{\circ}$ inclined orbit at $650 \mathrm{~km}$ altitude on 12 August 2003. The ACE-FTS operates in solar occultation, measuring a maximum of 15 sunrises and 15 sunsets a day. The level 1 data are transmittance spectra, obtained by dividing each spectrum of the occultation sequence by a corresponding exo-atmospheric high sun spectrum. An occultation sequence usually spans the altitude range from the upper troposphere to the mesosphere at an average vertical resolution of $4 \mathrm{~km}$. In the most favorable cases, however, sounding deep into the troposphere, down to $5 \mathrm{~km}$, is possible. The ACE-FTS spectra are characterized by a very high signal-to-noise ratio, in excess of 300:1, over much of the spectral range covered, which provide a unique opportunity to probe some of the less abundant trace species, otherwise inaccessible by other space-based remote-sensing techniques. Previous studies have recently reported on the measurements of methanol $\left(\mathrm{CH}_{3} \mathrm{OH}\right)$ (Dufour et al., 2006), formic acid ( $\mathrm{HCOOH}$ ) (Rinsland et al., 2006) and hydrogen peroxide $\left(\mathrm{H}_{2} \mathrm{O}_{2}\right)$ (Rinsland et al., 2007) from the ACE-FTS spectra.
Retrieval of temperature and trace gases from the ACEFTS spectra are performed operationally using a multiple microwindow, global fit approach relying on a standard leastsquare minimization scheme (Boone et al., 2005). The volume mixing ratios (vmrs) for more than a dozen atmospheric species are retrieved simultaneously. Here we rely on version 2.2 of the ACE retrieval set, which is currently under extensive validation. The version 2.2 data are provided both on the retrieval grid and on a constant $1 \mathrm{~km}$ vertical grid, using an a posteriori piecewise quadratic interpolation scheme. For tropospheric studies we are particularly interested in carbon monoxide $(\mathrm{CO})$ and hydrogen cyanide $(\mathrm{HCN})$, which are respectively good tracers of global pollution and biomass burning, in the non-methane hydrocarbons ethane $\left(\mathrm{C}_{2} \mathrm{H}_{6}\right)$ and ethyne $\left(\mathrm{C}_{2} \mathrm{H}_{2}\right)$, as well as nitric acid $\left(\mathrm{HNO}_{3}\right)$, which we use as an indicator of the $\mathrm{NO}_{\mathrm{x}}$ emissions. For $\mathrm{HNO}_{3}$, it is worth pointing out that we do not use the version 2.2 retrievals but an independent set, which was optimized for the troposphere by only considering lines within the $v_{5}-2 v_{9}$ bands in the atmospheric window.

In the course of our studies with the ACE-FTS level 2 products, we have identified an occultation sequence showing relatively high levels of $\mathrm{CO}, \mathrm{HCN}, \mathrm{C}_{2} \mathrm{H}_{6}$ and $\mathrm{C}_{2} \mathrm{H}_{2}$ in the upper troposphere, over Southern Africa. The enhancements in the volume mixing ratios of these species with respect to usual cases can best be identified by analyzing zonal distributions, obtained from the measurements made over several months of ACE operation. This is illustrated in Fig. 1, which shows the vmrs of the four species at $11.5 \mathrm{~km}$, averaged on a $4^{\circ}$ latitude $\times 8^{\circ}$ longitude grid for the months September to November 2005. Their analysis reveals that elevated vmr values for $\mathrm{CO}, \mathrm{HCN}, \mathrm{C}_{2} \mathrm{H}_{6}$ and $\mathrm{C}_{2} \mathrm{H}_{2}$ are found along a belt extending from the equator to $40^{\circ}$ southern latitudes, thus covering parts of the tropical forests in South America as well as Southern Africa and Australia. Among the tropical occultations, one is remarkable in the sense that it is also characterized by unusually high mid- and upper-tropospheric vmrs of $\mathrm{HNO}_{3}(0.51 \mathrm{ppbv}$ at $11.5 \mathrm{~km}$, see Fig. 2$)$ in addition to those of the above-mentioned species (163 ppbv for $\mathrm{CO} ; 0.71,1.03$ and $0.23 \mathrm{ppbv}$ for $\mathrm{HCN}, \mathrm{C}_{2} \mathrm{H}_{6}$ and $\mathrm{C}_{2} \mathrm{H}_{2}$ at $11.5 \mathrm{~km}$ respectively). This occultation is located on the East Coast of Tanzania, at $6.95^{\circ} \mathrm{S}$ latitude and $39.42^{\circ} \mathrm{E}$ longitude and was measured during a sunset on 8 October 2005 (black circle in Fig. 1). This paper focuses on the analysis of this particular plume. A background occultation (red circle in Fig. 1), measured the day after at similar latitude is used to quantify the level of enhancement in the concentration of the different pollutants.

\subsection{Model simulation of the $\mathrm{CO}$ distribution}

In order to identify the origin of the observed plume, we have used simulations of $\mathrm{CO}$ from the global chemistry transport model LMDz-INCA, which couples the general circulation model LMDz (Laboratoire de Météorologie Dynamique, 

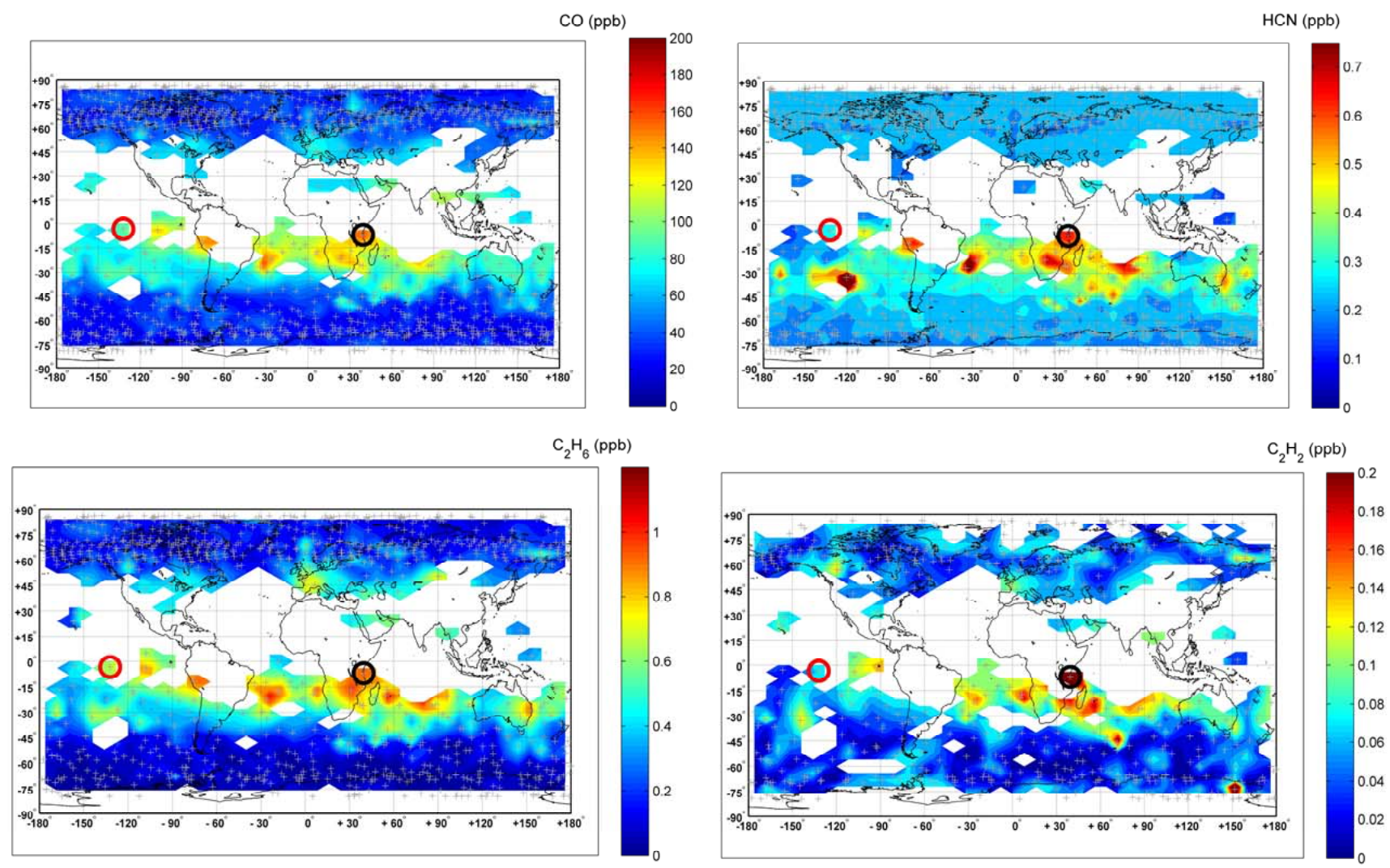

Fig. 1. Zonal distributions of $\mathrm{CO}, \mathrm{HCN}, \mathrm{C}_{2} \mathrm{H}_{6}$ and $\mathrm{C}_{2} \mathrm{H}_{2}$ volume mixing ratios at a tangent altitude of $11.5 \mathrm{~km}$, as obtained from the ACE version 2.2 processing. The data are averaged on a $4^{\circ}$ latitude $\times 8^{\circ}$ longitude grid using ACE-FTS measurements for the months September to November 2005; the color levels are saturated to highlight the elevated values in the Southern Hemisphere. The crosses identify the ACE measurements locations while the black and red circles shows the location of the fire occultation (ss11607 measured on 8 October 2005 on the East coast of Tanzania), and the background occultation (ss11615 measured on 9 October 2005, at a similar latitude). The ss notation refers to a sunset.

zoom) (Sadourny and Laval, 1984) and the INCA (Interactive Chemistry and Aerosols) chemistry module (Hauglustaine et al., 2004). CO was chosen because it has a lifetime of several weeks in the free and upper troposphere, making it a good tracer of the intra-hemispheric transport of pollution.

The INCA chemistry module includes 86 chemical species and involves 332 reactions (Hauglustaine et al., 2004). For the present model simulation, we rely on the LMDz version 4 and INCA version 2 in the nudged version of the model, driven by meteorological fields (winds and temperature) from the European Center for Medium-range Weather Forecasts reanalyses (ECMWF, ERA15), and using the Kerry Emanuel convection scheme (Emanuel and ZivkovicRothman, 1999). We use the biomass burning emissions from the Global Fire Emissions Database (GFED) version 2 (van der Werf et al., 2006), redistributed using the Along Track Scanning Radiometer (ATSR) fire detection.

The model simulations are performed with a horizontal resolution of $3.75^{\circ}$ in longitude $\times 2.5^{\circ}$ in latitude on 19 vertical levels extending from the surface to $3 \mathrm{hPa}$. As in the recent work of Turquety et al. (2007) ${ }^{1}$, regional CO tracers from eleven independent geographical zones have also been included to track the origin of the observed CO. In the Southern Hemisphere, the relevant source regions have been divided into four zones: South America, Southern Africa, Indonesia and Australia.

\subsection{Radiative transfer simulations and retrievals in the tro- posphere}

Measuring the composition of the plume beyond the standard ACE-FTS level 2 products requires the retrieval of concentration profiles from weak signatures, which are most frequently overlapped by strong absorption lines in the troposphere. An accurate modeling of the occultation spectra is therefore mandatory. For this work, we use the Atmosphit line-by-line

\footnotetext{
${ }^{1}$ Turquety, S., et al.: Long range transport of CO from Asia: complementarity of satellite observations from nadir (MOPITT, SCIAMACHY) and solar occultation (ACE-FTS) instruments, in preparation, 2007.
} 


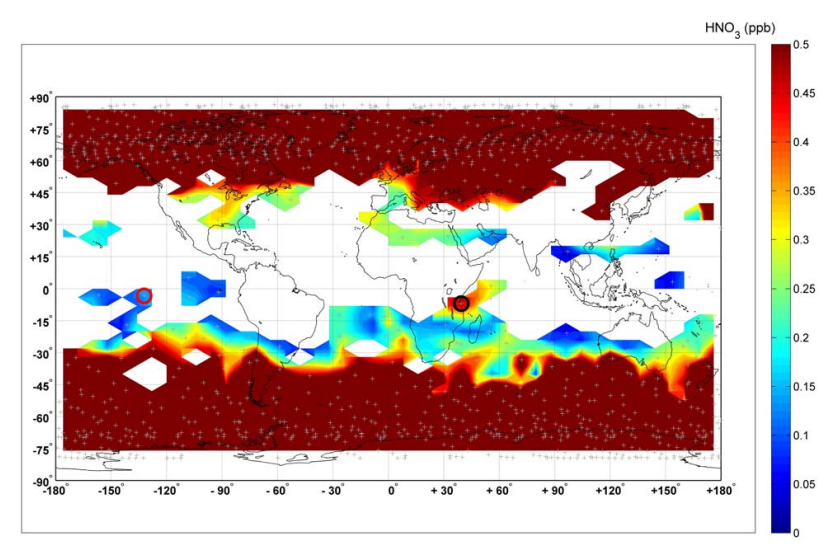

Fig. 2. Same as Fig. 1 for the HNO3 vmr at $11.5 \mathrm{~km}$.

(a)

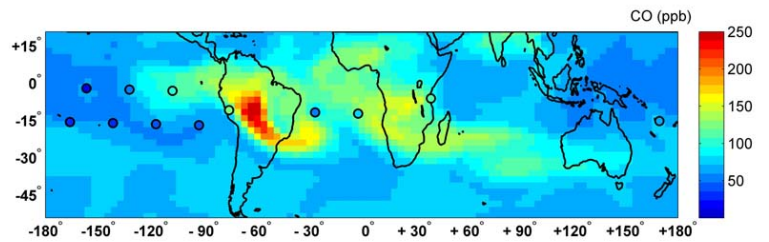

(b)

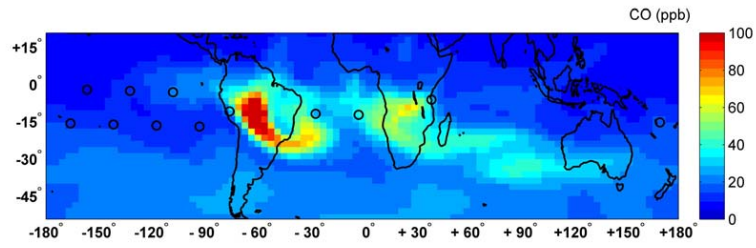

Fig. 3. LMDz-INCA simulations of the CO fields ( $\mathrm{vmr}$ in $\mathrm{ppb}$ ) at $250 \mathrm{hPa}$ in the Southern Hemisphere for the 3-day period from 7 October to 9 October 2005. Comparison of (a) the total CO with (b) the biomass burning contribution. Notice the different color scale. The locations of the ACE-FTS occultations during the three days are shown by black circles.

radiative transfer model and inversion software that was used for earlier studies with the ACE-FTS (Clerbaux et al., 2005). However, in contrast to the Clerbaux et al. (2005) work, we have adopted here a standard Levenberg-Marquardt minimization scheme, which does not depend upon a priori information and thus reduces possible false identifications.

The retrievals use the tangent altitudes, pressure and temperature profiles derived from the ACE operational processing (version 2.2). Unapodised spectra are used, with an Instrument Line Shape (ILS) formulation similar as that prescribed in Boone et al. (2005), thus accounting for finite field-of-view and self-apodisation effects. The version $2.2 \mathrm{vmrs}$ of all known interfering species are also used as initial profiles but are systematically readjusted in the target spectral regions in order to provide the best achievable fits. The line parameters and absorption cross-sections are from HITRAN 2004 including all recent updates (Rothman
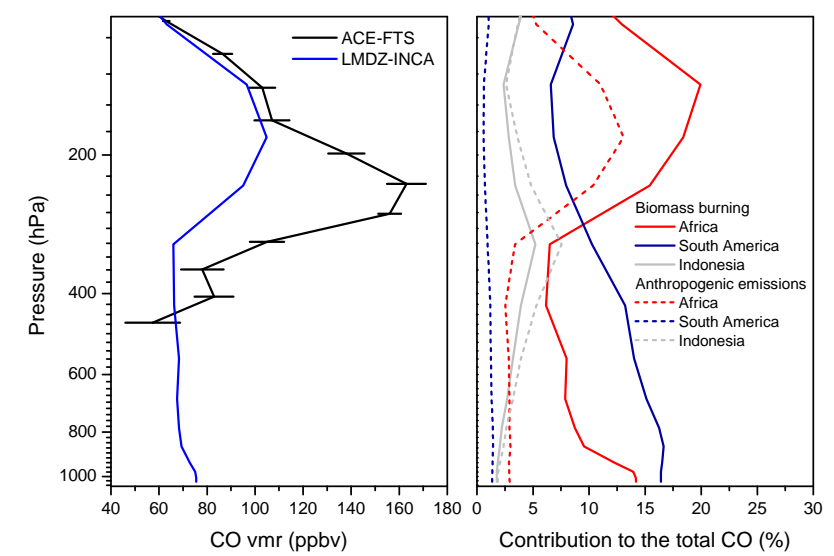

Fig. 4. (left) Comparison between the LMDz-INCA simulated and ACE-FTS measured CO profile for the fire plume (ss11607). The error bars on the ACE-FTS profile show the statistical error associated with the retrieval. (Right) Regional contributions to the total $\mathrm{CO}$, as simulated using LMDZ-INCA.

et al., 2005). For species missing in the HITRAN database $\left(\mathrm{C}_{3} \mathrm{H}_{6} \mathrm{O}\right.$ and $\mathrm{C}_{3} \mathrm{H}_{4}$ hereafter), the absorption cross-sections from the Northwest-Infrared Vapor phase infrared spectral library (Sharpe et al., 2004) have been used.

\section{Results and discussion}

\subsection{Plume origin}

The LMDz-INCA simulations of the CO transport in the upper troposphere are displayed in Fig. 3 for a three-day period between 7 and 9 October 2005, which includes both the target and background occultations highlighted in Fig. 1 and in Fig. 2. The $\mathrm{CO}$ vmrs are given at $250 \mathrm{hPa}$, which corresponds approximately to the altitude of $11.5 \mathrm{~km}$ at which the zonal distributions of Figs. 1 and 2 are drawn.

Figure 3 compares the model biomass burning contribution (bottom panel) to the total $\mathrm{CO}$ (top panel) during the time period of interest. It clearly shows that intense burning occurred in the South American tropical forests, as well as in the Southern part of Africa, which is consistent with ATSR fire counts (http://dup.esrin.esa.it/ionia/wfa/index.asp).

Figure 4 compares further (left panel), at the location of the target occultation on the East coast of Tanzania (ss11607), the CO profile measured by the ACE-FTS with the associated statistical uncertainties from the retrievals, and simulated by LMDz-INCA. The agreement between both profiles is good, except between $300 \mathrm{hPa}(\sim 10 \mathrm{~km})$ and $180 \mathrm{hPa}(\sim 13 \mathrm{~km})$, where the measurements show a strong $\mathrm{CO}$ enhancement. The latter is not reproduced by the model, thereby pointing to the remarkable event investigated here. The panel on the right of Fig. 4 shows the contributions of biomass burning and anthropogenic emissions to the total 
Table 1. Spectral windows for the detection and profile retrievals of $\mathrm{C}_{2} \mathrm{H}_{4}, \mathrm{NH}_{3}, \mathrm{PAN}, \mathrm{C}_{3} \mathrm{H}_{6} \mathrm{O}, \mathrm{H}_{2} \mathrm{CO}$ and $\mathrm{C}_{3} \mathrm{H}_{4}$. The principal interfering species are given in the last column.

\begin{tabular}{clc}
\hline Species & Spectral windows $\left(\mathrm{cm}^{-1}\right)$ & Interfering species \\
\hline $\mathrm{C}_{2} \mathrm{H}_{4}$ & $938.00-946.50$ & $\mathrm{H}_{2} \mathrm{O}, \mathrm{CO}_{2}, \mathrm{~N}_{2} \mathrm{O}$ \\
& $948.20-960.00$ & \\
$\mathrm{NH}_{3}$ & $960.00-968.30$ & $\mathrm{H}_{2} \mathrm{O}, \mathrm{CO}_{2}, \mathrm{O}_{3}, \mathrm{~N}_{2} \mathrm{O}$ \\
$\mathrm{PAN}$ & $776.00-790.40$ & $\mathrm{H}_{2} \mathrm{O}, \mathrm{CO}_{2}, \mathrm{O}_{3}, \mathrm{~N}_{2} \mathrm{O}, \mathrm{CH}_{4}, \mathrm{HNO}_{3}, \mathrm{CFC}-12, \mathrm{HCFC}-22, \mathrm{HNO}_{4}, \mathrm{CCl}_{4}$ \\
& $1140.15-1180.45$ & \\
$\mathrm{C}_{3} \mathrm{H}_{6} \mathrm{O}$ & $1361.90-1367.50$ & $\mathrm{H}_{2} \mathrm{O}, \mathrm{CO}_{2}, \mathrm{CH}_{4}$ \\
$\mathrm{H}_{2} \mathrm{CO}$ & $2753.90-2860.75$ & $\mathrm{H}_{2} \mathrm{O}, \mathrm{O}_{3}, \mathrm{~N}_{2} \mathrm{O}, \mathrm{CH}_{4}$ \\
$\mathrm{C}_{3} \mathrm{H}_{4}$ & $3300.00-3360.00$ & $\mathrm{H}_{2} \mathrm{O}, \mathrm{CO}_{2}, \mathrm{~N}_{2} \mathrm{O}, \mathrm{HCN}, \mathrm{C}_{2} \mathrm{H}_{2}$ \\
\hline
\end{tabular}

$\mathrm{CO}$, separated in regional contributions from South America, Africa and Indonesia. Although the main circulation patterns in the upper troposphere above Africa seem to blow the CO to the west before being redirected eastwards (Fig. 3), this regional analysis demonstrates that the dominant contribution to the total modeled CO for ss 11607 comes from African biomass burning and to a lesser extent anthropogenic emissions. It suggests therefore that this plume sampled by the ACE-FTS likely originates from a relatively nearby fire and is relatively young. Further evidence for the recent character of the plume is provided by its spectral and chemical composition analyses, described hereafter.

\subsection{Spectral analysis}

In this section, we present a detailed spectral analysis of the occultation probing the young biomass burning plume, which is motivated by the observation of significant features emerging from the noise in the residual spectra. The latter are obtained by subtracting simulated spectra based on the ACE version 2.2 data products from the observed spectra in the upper troposphere. The presence of residual spectral features suggests that absorption by trace species unaccounted for in the operational processing occurs in this altitude region. The top panel in Fig. 5 displays such a case for $\mathrm{HCOOH}$ and $\mathrm{CH}_{3} \mathrm{OH}$. Similar spectral residuals for these species have been reported previously from the ACE measurements in aged biomass burning plumes, transported far from their emission source (Dufour et al., 2006; Rinsland et al., 2006). The vertical profiles for the occultation analyzed here, retrieved from $5.5 \mathrm{~km}$ to $20 \mathrm{~km}$, show maximum values of about $2 \mathrm{ppbv}$ for $\mathrm{CH}_{3} \mathrm{OH}$ and $0.4 \mathrm{ppbv}$ for $\mathrm{HCOOH}$ in the upper troposphere (Fig. 6), which are within the range of mixing ratios earlier reported for aged plumes.

A more careful analysis of the spectrum at $11 \mathrm{~km}$ in the upper troposphere reveals the signatures of other biomass burning related species in specific windows (Fig. 5), also summarized in Table 1 along with the principal interferences:

$-\mathrm{C}_{2} \mathrm{H}_{4}$ : It is observed in the region near $950 \mathrm{~cm}^{-1}$, which is dominated by the $v_{7}$ vibrational band, with additional contribution of the $v_{4}$ and $v_{10}$ bands (Rusinek et al., 1998). This region, which includes the $v_{7} Q$-branch at $945.45 \mathrm{~cm}^{-1}$, partly overlapped by a strong $\mathrm{CO}_{2}$ line, is similar to that also used to measure $\mathrm{C}_{2} \mathrm{H}_{4}$ from the ground-based FTIR instruments (Rinsland et al., 2005).

- $\mathrm{NH}_{3}$ : It is tentatively identified by several rotational lines around $966 \mathrm{~cm}^{-1}$ in the $\nu_{2}$ vibrational band (Kleiner et al., 2003). This region was also amongst the set of microwindows used for the retrieval of $\mathrm{NH}_{3}$ from MIPAS (Burgess et al., 2006).

- PAN: The infrared absorption cross-section of PAN is characterized by a series of structureless vibrational bands (Allen et al., 2005a; Allen et al., 2005b), the strongest of which (at $\sim 1740 \mathrm{~cm}^{-1}$ ) is masked by water vapour lines and cannot be used for remote sensing. In the present spectrum, we find that PAN is best measured using the band at $1163 \mathrm{~cm}^{-1}$ (CO stretching), although the somewhat weaker band at $794 \mathrm{~cm}^{-1}\left(\mathrm{NO}_{2}\right.$ bending) is observed as well. These observations confirm those made by the MIPAS-B2 balloon instrument (Remedios et al., 2007). Recently, PAN retrievals from the MIPAS satellite instrument have also been successfully performed, using a portion of the PAN $794 \mathrm{~cm}^{-1}$ band where the instrument signal-to-noise ratio is higher than in the other PAN absorption bands (Glatthor et al., 2007).

- $\mathrm{C}_{3} \mathrm{H}_{6} \mathrm{O}$ : Acetone is detected here using a prominent $Q$-branch at $1365.5 \mathrm{~cm}^{-1}$ (CH bending mode). This window obviously offers a good alternative for sensing acetone, which was previously done using the $v_{17} \mathrm{C}-\mathrm{C}$ stretch at $1216 \mathrm{~cm}^{-1}$ (Remedios et al., 2006; Remedios et al., 2007).

- $\mathrm{H}_{2} \mathrm{CO}$ : A series of $\mathrm{H}_{2} \mathrm{CO}$ lines have been observed in the ACE-FTS spectra using a small set of microwindows between 2753.90 and $2860.75 \mathrm{~cm}^{-1}$ within the strong $v_{1} / \nu_{5}$ vibrational bands. (Perrin et al., 2006). 

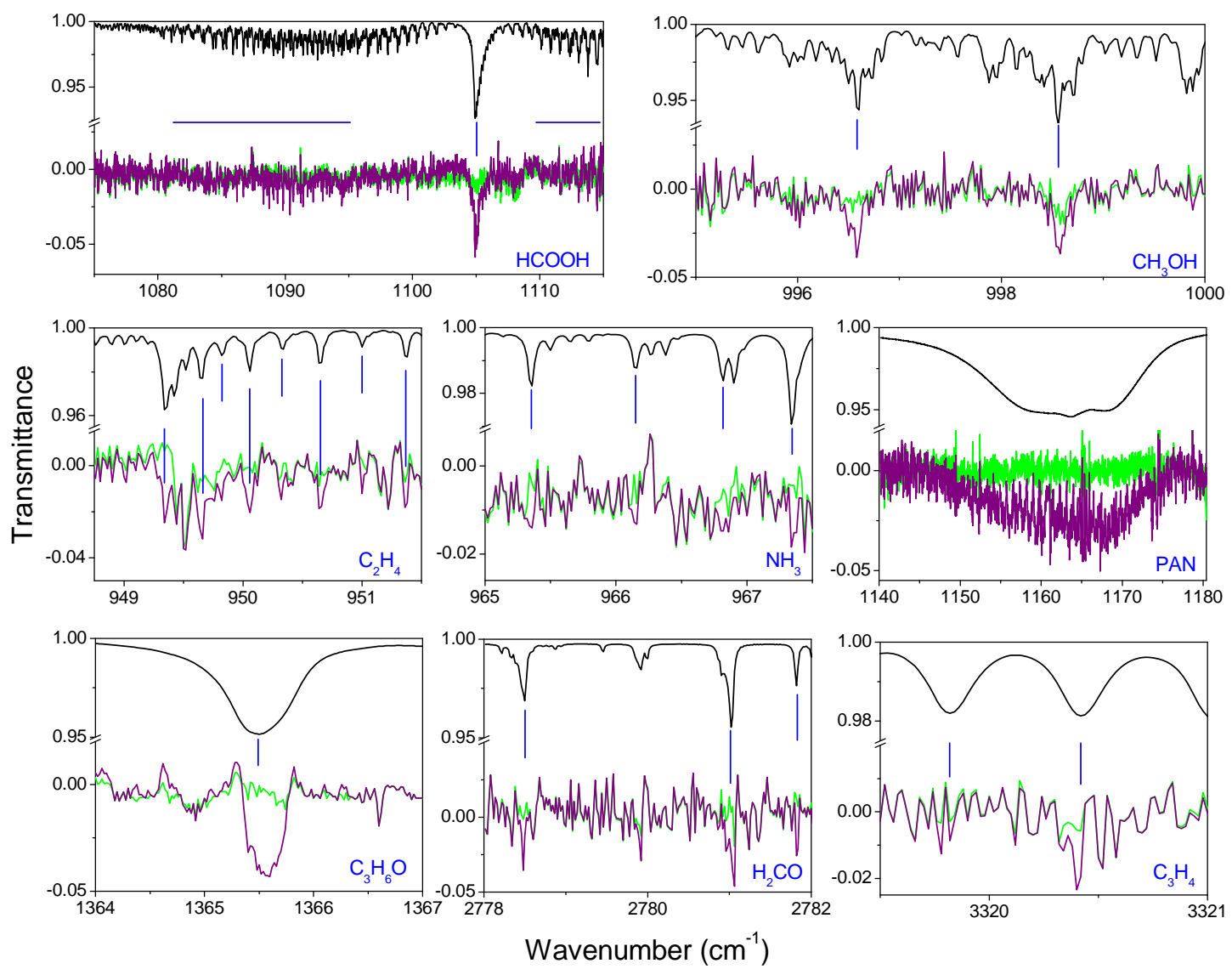

Fig. 5. Spectral fits of the spectrum at a tangent altitude of $11 \mathrm{~km}\left(12 \mathrm{~km}\right.$ in the case of $\left.\mathrm{NH}_{3}\right)$ in the regions where weak absorptions are detected, corresponding to contributions of $\mathrm{CH}_{3} \mathrm{OH}, \mathrm{HCOOH}, \mathrm{C}_{2} \mathrm{H}_{4}, \mathrm{NH}_{3}, \mathrm{PAN}, \mathrm{C}_{3} \mathrm{H}_{6} \mathrm{O}, \mathrm{H}_{2} \mathrm{CO}$ and $\mathrm{C}_{3} \mathrm{H}_{4}$. The green and purple lines are the spectral residuals obtained by fitting the observation, respectively, including and excluding the absorption by the target species in the retrieval process. The black lines represent the individual absorption contribution of the molecule and the vertical blue lines indicate the position of the principal spectral features.

The most prominent feature is observed at $2781 \mathrm{~cm}^{-1}$ (Fig. 5).

$-\mathrm{C}_{3} \mathrm{H}_{4}$ : Several weak features are observed in the ACEFTS residual spectrum around $3320 \mathrm{~cm}^{-1}$, in the region of the $v_{1}$ vibrational band of propyne (El Idrissi et al., 2001). Due to their weakness, the assignment of these features to propyne is, however, only tentative.

For $\mathrm{C}_{2} \mathrm{H}_{4}, \mathrm{H}_{2} \mathrm{CO}, \mathrm{C}_{3} \mathrm{H}_{6} \mathrm{O}$, PAN and, if confirmed $\mathrm{C}_{3} \mathrm{H}_{4}$, the observations made here are the first reported measurements from infrared occultation sounders. They complement and confirm recently reported PAN, $\mathrm{C}_{3} \mathrm{H}_{6} \mathrm{O}$ and $\mathrm{NH}_{3}$ measurements from MIPAS (Burgess et al., 2006; Glatthor et al., 2007; Remedios et al., 2006). Finally it is worth noting that although we have observed additional residual spectral features which might be attributed to absorption by propane $\left(\mathrm{C}_{3} \mathrm{H}_{8}\right)$ and butane $\left(\mathrm{C}_{4} \mathrm{H}_{10}\right)$, we have not been able to confirm the detection, mainly because of the lack of proper spectroscopic data in the appropriate micro-windows. In ad- dition, searches for other fire products often observed by airborne measurements, such as propene $\left(\mathrm{C}_{3} \mathrm{H}_{6}\right)$, acetaldehyde $\left(\mathrm{CH}_{3} \mathrm{CHO}\right)$, acetic acid $\left(\mathrm{CH}_{3} \mathrm{COOH}\right)$ or acetonitrile $\left(\mathrm{CH}_{3} \mathrm{CN}\right)$ have been unsuccessful on this occultation.

\subsection{Photochemical age}

Useful information on the photochemical age of the plume can be extracted at this point from the simultaneous detection of NMHCs. In our case, following the classification proposed by Mauzerall et al. (1998), the observation of $\mathrm{C}_{2} \mathrm{H}_{4}$, which as a mean lifetime ranging from half a day in the lower troposphere to 1.2 days in the upper troposphere, categorizes the plume as "recent" and demonstrate that it has likely not traveled for more than a day. This age, which is consistent with the origin of the plume estimated from the model simulations, is further corroborated by the measurement of $\mathrm{H}_{2} \mathrm{CO}$ and possibly $\mathrm{NH}_{3}$, which are considered to be direct pyrolysis and smoldering emission products, respectively, and which have a lifetime of less than two days. Recent plumes 
are generally found nearby the source region in the free troposphere. This is obviously the situation encountered for the occultation studied here, with the particularity, however, that the species are observed at relatively high altitude, likely as a result of strong vertical uplift.

\subsection{Concentration profiles}

The profiles retrieved from 5 to $20 \mathrm{~km}$ for the six newly identified species are displayed in Fig. 6, along with those of other constituents, directly emitted or formed by photochemical reactions within the plume. The spectral windows used for the retrievals are those listed in Table 1. It is worth noting that the microwindows are relatively wide in order to facilitate the spectral analysis of the residual spectrum but that they are accordingly not optimized for the processing of other occultations. The first striking observation from Fig. 6 is that the maximum vmr is located at $11-12 \mathrm{~km}$ for almost all species. For $\mathrm{C}_{2} \mathrm{H}_{4}$ and $\mathrm{NH}_{3}$ the maximum at that altitude is less pronounced because of higher vmrs in the lower levels. As $\mathrm{C}_{2} \mathrm{H}_{4}$ and $\mathrm{NH}_{3}$ are two short-lived species, this could indicate the occurrence of photochemical losses as the plume rises. Globally, however, the high level of correlation among the species points to a common emission source.

Table 2 lists, on the basis of the retrieved profiles at $11.5 \mathrm{~km}$, the emission ratios with respect to $\mathrm{CO}$, calculated as $\Delta[\mathrm{X}] / \Delta[\mathrm{CO}]$, where $[\mathrm{X}]$ and $[\mathrm{CO}]$ are the volume mixing ratio of the target species and of carbon monoxide respectively and $\Delta$ indicates the enhancement of a compound in the plume relative to its background value; $\Delta[\mathrm{X}]$ is usually referred to as the excess mixing ratio. In Table 2 , the background values are those of the background occultation shown in Fig. 1 and Fig. 2, with a vanishing vmr assumed for those species which could not be retrieved. One should note that very similar emission ratios can be calculated by considering as background values the vmrs of the fire occultation itself, but at a higher altitude than that of the enhancement.

From the analysis of Table 2, it can be observed that the retrieved vmrs in the plume at the maximum of the profiles are larger than the corresponding values in the background occultation, with the exception of the long-lived $\mathrm{CH}_{4}$ and OCS molecules. For instance the enhancement in $\mathrm{CO}$ around $12 \mathrm{~km}$ is $96 \mathrm{ppbv}$. On a relative basis, the level of enhancement with respect to the background vmr $\left(100 \times \Delta[\mathrm{X}] /[\mathrm{X}]_{\text {background }}\right)$ is modest for $\mathrm{CH}_{3} \mathrm{Cl}(+50 \%)$ but significant for $\mathrm{C}_{2} \mathrm{H}_{2}(+2200 \%), \mathrm{HNO}_{3}(+1175 \%)$ and obviously for all the other species undetected in the background occultation. We also note that the emission ratios for the fire occultation are largest for methanol and acetone, which could be rationalized by the fact that these species are not only emitted but also formed by photochemical reactions inside the plume. Finally, we do not find significant ozone enhancements in the upper troposphere between the two occultations $(+37 \%)$, thus suggesting that photochemical transformations have been limited in time.
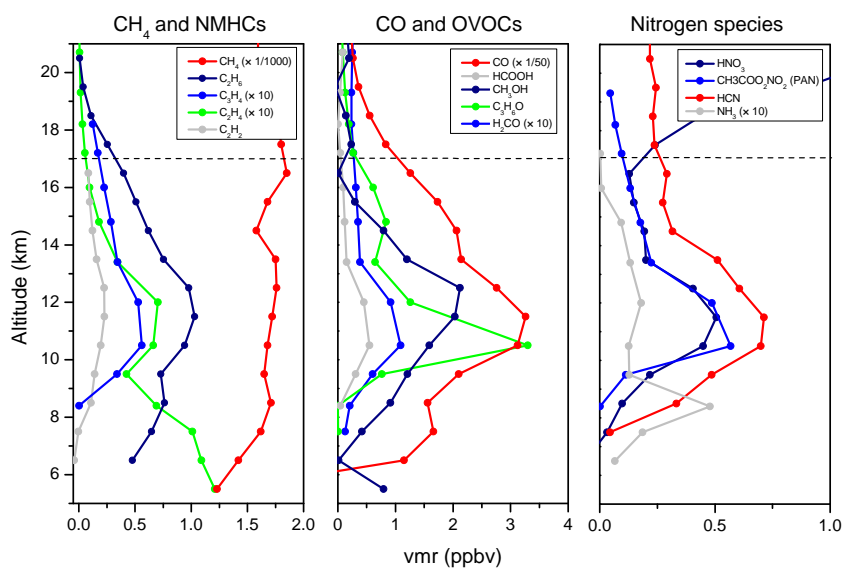

Fig. 6. Volume mixing ratio for several (a) $\mathrm{CH}_{4}$ and NMHCs, (b) $\mathrm{CO}$ and OVOCs and (c) Nitrogen-containing species, found with elevated upper tropospheric concentrations. The dashed lines indicate the tropopause altitude, as inferred from the retrieved temperature profile.

Although a robust comparison with earlier work cannot be performed based on the single event analyzed here and due to the difficulty in locating precisely the source region, we note that the emission ratios lie in the range of values commonly reported from airborne measurements. Table 2 compares, for instance, our calculated values to the initial emission ratios reported in Yokelson et al. (2003) and of mean hydrocarbon enhancement ratios in fresh, recent and aged plumes from Mauzerall et al. (1998). Although not directly comparable to the situation described here, we observe reasonable agreement with the Yokelson et al. (2003) averaged values for the species with medium lifetimes $\left(\mathrm{C}_{2} \mathrm{H}_{2}, \mathrm{HCOOH}\right.$, $\mathrm{CH}_{3} \mathrm{OH}, \mathrm{HCN}$ ) but large discrepancies for the shorter lived ones $\left(\mathrm{C}_{2} \mathrm{H}_{4}, \mathrm{H}_{2} \mathrm{CO}, \mathrm{NH}_{3}\right)$. The observation of much smaller emission ratios for the short-lived species in our case (more than one order of magnitude smaller) obviously points to the fact that the chemical composition of the plume has been altered by a series of fast photochemical reactions. The comparison with the Mauzerall et al. (1998) values for the NMHCs gives further evidence of the fresh to recent character of the plume investigated here. Interestingly, we also note the $\mathrm{NH}_{3} \mathrm{vmr}$ in the upper troposphere is within the range of values found by the MIPAS analyses (Burgess et al., 2006). Finally, based on similar vmrs retrieved for PAN and $\mathrm{HNO}_{3}$ ( $\sim 0.5 \mathrm{ppbv}$ at the maximum), we do not find evidence, in contrast to other studies (Mauzerall et al., 1998), that PAN is the favored oxidation product of $\mathrm{NO}_{\mathrm{x}}$ in burning plumes.

\section{Conclusions and perspectives}

Analyses of an ACE-FTS solar occultation sequence over the East Coast of Tanzania, show elevated mixing ratios for a series of tropospheric species. Model simulations using 
Table 2. Volume mixing ratio (ppbv) of target species at $11.5 \mathrm{~km}$ for the occultation ss 11607 within a biomass burning plume and for the background occultation ss11615 (Fig. 1); the number in parentheses represent the statistical error from the retrieval. Note that $s s$ refers to sunset. The emission ratios with respect to carbon monoxide for the occultation ss 11607 are given and compared to literature data in the last two columns. For the calculation of the emission ratio when no profiles could be retrieved from the background occultation, a vanishing background vmr has been assumed.

\begin{tabular}{|c|c|c|c|c|c|c|c|c|}
\hline & \multirow[t]{3}{*}{ Species } & \multicolumn{2}{|c|}{ vmr (ppbv) at $11.5 \mathrm{~km}$} & \multicolumn{5}{|c|}{$100 \times \Delta[\mathrm{X}] / \Delta[\mathrm{CO}]$} \\
\hline & & \multirow[t]{2}{*}{ ss11607 } & \multirow[t]{2}{*}{ ss11615 } & \multirow[t]{2}{*}{ this work } & \multirow[t]{2}{*}{ Yokelson et al. ${ }^{\mathrm{b}}$} & \multicolumn{3}{|c|}{ Mauzerall et al..$^{\mathrm{c}}$} \\
\hline & & & & & & fresh & recent & aged \\
\hline Carbon monoxide & $\mathrm{CO}^{\mathrm{a}}$ & $163(8)$ & $67(3)$ & & & & & \\
\hline Methane & $\mathrm{CH}_{4}^{\mathrm{a}}$ & $1720(62)$ & $1730(40)$ & & & & & \\
\hline \multicolumn{9}{|l|}{ NMHCs } \\
\hline Ethane & $\mathrm{C}_{2} \mathrm{H}_{6}^{\mathrm{a}}$ & $1.03(0.11)$ & $0.47(0.05)$ & 0.59 & - & $0.75(0.06)$ & $0.59(0.07)$ & $0.71(0.11)$ \\
\hline Ethene & $\mathrm{C}_{2} \mathrm{H}_{4}$ & $0.07(0.02)$ & - & 0.07 & $1.71(0.33)$ & $0.69(0.13)$ & $0.13(0.03)$ & - \\
\hline Ethyne & $\mathrm{C}_{2} \mathrm{H}_{2}^{\mathrm{a}}$ & $0.23(0.04)$ & $0.01(0.01)$ & 0.22 & $0.43(0.13)$ & $0.42(0.04)$ & $0.34(0.05)$ & $0.26(0.02)$ \\
\hline Propyne & $\mathrm{C}_{3} \mathrm{H}_{4}^{2}$ & $0.05(0.01)$ & - & 0.05 & - & - & - & - \\
\hline \multicolumn{9}{|l|}{ OVOCs } \\
\hline Formic acid & $\mathrm{HCOOH}$ & $0.49(0.01)$ & - & 0.51 & $0.59(0.22)$ & - & - & - \\
\hline Methanol & $\mathrm{CH}_{3} \mathrm{OH}$ & $2.03(0.36)$ & - & 2.12 & $1.44(0.30)$ & - & - & - \\
\hline Formaldehyde & $\mathrm{H}_{2} \mathrm{CO}$ & $0.09(0.01)$ & - & 0.10 & $1.45(0.43)$ & - & - & - \\
\hline Acetone & $\mathrm{C}_{3} \mathrm{H}_{6} \mathrm{O}$ & $1.95(0.02)$ & - & 2.04 & - & - & - & - \\
\hline \multicolumn{9}{|l|}{$N$-species } \\
\hline Hydrogen cyanide & $\mathrm{HCN}^{\mathrm{a}}$ & $0.71(0.03)$ & $0.16(0.02)$ & 0.57 & $0.85(0.29)$ & - & - & - \\
\hline Nitric acid & $\mathrm{HNO}_{3}^{\mathrm{a}}$ & $0.51(0.09)$ & $0.04(0.03)$ & 0.49 & - & - & - & - \\
\hline Ammonia & $\mathrm{NH}_{3}$ & $0.018(0.001)$ & - & 0.02 & $0.70(0.41)$ & - & - & - \\
\hline PAN & $\mathrm{CH}_{3} \mathrm{CO}_{3} \mathrm{NO}_{2}$ & $0.52(0.02)$ & - & 0.54 & - & - & - & - \\
\hline Methyl chloride & $\mathrm{CH}_{3} \mathrm{Cl}^{\mathrm{a}}$ & $0.96(0.47)$ & $0.65(0.24)$ & 0.33 & - & - & - & - \\
\hline Carbonyl sufide & OCS & $0.43(0.02)$ & $0.44(0.01)$ & -0.01 & - & - & - & - \\
\hline
\end{tabular}

a Operational level 2 products from the ACE-FTS processing.

${ }^{\mathrm{b}}$ Study average value with $\sigma$ variability taken from Table 2 of Yokelson et al. (2003).

c Values and $\sigma$ variability taken from Table 2 of Mauzerall et al. (1998).

LMDz-INCA gave evidence that the plume sampled is relatively young and that it likely originated from a nearby fire. We have shown that because of the large spectral coverage, the high spectral resolution and the excellent signal-to-noise ratio of the ACE-FTS, weakly absorbing NMHCs, OVOCs and nitrogen-containing species could be detected in the fire plume. The spectral signatures of $\mathrm{C}_{2} \mathrm{H}_{4}, \mathrm{H}_{2} \mathrm{CO}, \mathrm{C}_{3} \mathrm{H}_{6} \mathrm{O}$, $\mathrm{HCOOH}, \mathrm{CH}_{3} \mathrm{OH}$, PAN have been clearly identified in the spectra. For $\mathrm{C}_{2} \mathrm{H}_{4}, \mathrm{H}_{2} \mathrm{CO}, \mathrm{C}_{3} \mathrm{H}_{6} \mathrm{O}$ and PAN these are the first reported simultaneous measurements by means of infrared spectroscopy from satellites. Tentative assignments of $\mathrm{NH}_{3}$ and $\mathrm{C}_{3} \mathrm{H}_{4}$ features in the residuals were also made. For all species vertical profiles have been successfully retrieved and compared to a series of other biomass burning products delivered by the operational ACE-FTS data processing, including the $\mathrm{CO}, \mathrm{HCN}, \mathrm{C}_{2} \mathrm{H}_{6}$ and $\mathrm{C}_{2} \mathrm{H}_{2}$ tracers. A marked maximum in the volume mixing ratio of all measured NMHCs, OVOCs and nitrogen-containing species, around $12 \mathrm{~km}$ in the upper troposphere, was reported for the occultation, suggesting a common emission source. Emission ratios with respect to $\mathrm{CO}$ were calculated using a reference occultation. The observation of species with a short lifetime suggests that the emission plume has an age of not more than one day. More generally, the results presented in this work open promising possibilities for the sensing of NMHCs and OVOCs by the ACE-FTS, and for further scientific studies on the influence of these compounds in the chemistry of the upper troposphere.

Acknowledgements. The authors thank M. Fromm for useful discussions. The research in Belgium was funded by the Fonds de la Recherche Scientifique (FRS-FNRS, Belgium), the Belgian State Federal Office for Scientific, Technical and Cultural Affairs and the European Space Agency (ESA-Prodex arrangement C90-219). Financial support by the "Actions de Recherche Concertées" (Communauté Française de Belgique) is also acknowledged. C. Clerbaux acknowledges the financial support of CNES (Centre National d'Etudes Spatiales, France) for attending the ACE Science team meetings. We would like to thank the Canadian Space Agency (CSA) and the Natural Sciences and Engineering Research Council (NSERC) of Canada for funding the ACE mission. P. F. Coheur is Research Associate with the FRS-FNRS (Belgium).

Edited by: M. van Roozendael 


\section{References}

Allen, G., Remedios, J. J., Newnham, D. A., Smith, K. M., and Monks, P. S.: Improved mid-infrared cross-sections for peroxyacetyl nitrate (PAN) vapour, Atmos. Chem. Phys., 5, 47-56, 2005a.

Allen, G., Remedios, J. J., and Smith, K. M.: Low temperature midinfrared cross-sections for peroxyacetyl nitrate (PAN) vapour, Atmos. Chem. Phys., 5, 3153-3158, 2005b.

Andreae, M. O. and Merlet, P.: Emission of trace gases and aerosols from biomass burning, G. Biogeochem. Cycles, 15, 955-966, doi:910.1029/2000GB001382, 2001.

Bernath, P. F., McElroy, C. T., Abrams, M. C., Boone, C. D., Butler, M., Camy-Peyret, C., Carleer, M., Clerbaux, C., Coheur, P. F., Colin, R., DeCola, P., Bernath, P. F., McElroy, C. T., Abrams, M. C., Boone, C. D., Butler, M., Camy-Peyret, C., Carleer, M., Clerbaux, C., Coheur, P. F., Colin, R., DeCola, P., DeMaziere, M., Drummond, J. R., Dufour, D., Evans, W. F. J., Fast, H., Fussen, D., Gilbert, K., Jennings, D. E., Llewellyn, E. J., Lowe, R. P., Mahieu, E., McConnell, J. C., McHugh, M., McLeod, S. D., Michaud, R., Midwinter, C., Nassar, R., Nichitiu, F., Nowlan, C., Rinsland, C. P., Rochon, Y. J., Rowlands, N., Semeniuk, K., Simon, P., Skelton, R., Sloan, J. J., Soucy, M. A., Strong, K., Tremblay, P., Turnbull, D., Walker, K. A., Walkty, I., Wardle, D. A., Wehrle, V., Zander, R., and Zou, J.: Atmospheric Chemistry Experiment (ACE): Mission overview, Geophys. Res. Lett., 32, L15S01, doi:10.1029/2005GL022386, 2005.

Boone, C. D., Nassar, R., Walker, K. A., Rochon, Y., McLeod, S. D., Rinsland, C. P., and Bernath, P. F.: Retrievals for the atmospheric chemistry experiment Fourier-transform spectrometer, Appl. Optics, 44, 7218-7231, 2005.

Burgess, A. B., Dudhia, A., Grainger, R. G., and Stevenson, D.: Progress in tropospheric ammonia retrieval from the MIPAS satellite instrument, Adv. Space Res., 37, 2218-2221, 2006.

Clerbaux, C., Coheur, P. F., Hurtmans, D., Barret, B., Carleer, M., Colin, R., Semeniuk, K., McConnell, J. C., Boone, C., and Bernath, P.: Carbon monoxide distribution from the ACEFTS solar occultation measurements, Geophys. Res. Lett., 32, L16S01, doi:10.1029/2005GL022394, 2005.

Dufour, G., Boone, C. D., Rinsland, C. P., and Bernath, P. F.: First space-borne measurements of methanol inside aged southern tropical to mid-latitude biomass burning plumes using the ACE-FTS instrument, Atmos. Chem. Phys., 6, 3463-3470, 2006, http://www.atmos-chem-phys.net/6/3463/2006/.

Edwards, D. P., Emmons, L. K., Gille, J. C., Chu, A., Attie, J. L., Giglio, L., Wood, S. W., Haywood, J., Deeter, M. N., Massie, S. T., Ziskin, D. C., and Drummond, J. R.: Satellite-observed pollution from Southern Hemisphere biomass burning, J. Geophys. Res., 111, D14312, doi:10.1029/2005JD006655, 2006.

El Idrissi, M. I., Lievin, J., Herman, M., Campargue, A., and Graner, G.: The vibrational energy pattern in propyne ( $\left.\left(\mathrm{CH}_{3} \mathrm{C}_{2} \mathrm{H}\right)-\mathrm{C}-12-\mathrm{C}-12\right)$, Chem. Phys., 265, 273-289, 2001.

Emanuel, K. A. and Zivkovic-Rothman, M.: Development and evaluation of a convection scheme for use in climate models, J. Atm. Sc., 56, 1766-1782, 1999.

Fromm, M., Tupper, A., Rosenfeld, D., Servranckx, R., and McRae, R.: Violent pyro-convective storm devastates Australia's capital and pollutes the stratosphere, Geophys. Res. Lett., 33, L05815, doi:10.1029/2005GL025161, 2006.

Glatthor, N., von Clarmann, T., Fischer, H., Funke, B., Grabowski,
U., Höpfner, M., Kellmann, S., Kiefer, M., Linden, A., Milz, M., Steck, T., and Stiller, G. P.: Global peroxyacetyl nitrate (PAN) retrieval in the upper troposphere from limb emission spectra of the Michelson Interferometer for Passive Atmospheric Sounding (MIPAS), Atmos. Chem. Phys. Discuss., 7, 1391-1420, 2007, http://www.atmos-chem-phys-discuss.net/7/1391/2007/.

Goode, J. G., Yokelson, R. J., Ward, D. E., Susott, R. A., Babbitt, R. E., Davies, M. A., and Hao, W. M.: Measurements of excess $\mathrm{O}_{3}, \mathrm{CO}_{2}, \mathrm{CO}, \mathrm{CH}_{4}, \mathrm{C}_{2} \mathrm{H}_{4}, \mathrm{C}_{2} \mathrm{H}_{2}, \mathrm{HCN}, \mathrm{NO}, \mathrm{NH}_{3}$, $\mathrm{HCOOH}, \mathrm{CH}_{3} \mathrm{COOH}, \mathrm{HCHO}$, and $\mathrm{CH}_{3} \mathrm{OH}$ in 1997 Alaskan biomass burning plumes by airborne fourier transform infrared spectroscopy (AFTIR), J. Geophys. Res., 105, 22 147-22 166, doi:22110.21029/22000JD900287, 2000.

Hauglustaine, D. A., Hourdin, F., Jourdain, L., Filiberti, M. A., Walters, S., Lamarque, J. F., and Holland, E. A.: Interactive chemistry in the Laboratoire de Meteorologie Dynamique general circulation model: Description and background tropospheric chemistry evaluation, J. Geophys. Res., 109, D04314, doi:10.1029/2003JD003957, 2004.

Hobbs, P. V., Sinha, P., Yokelson, R. J., Christian, T. J., Blake, D. R., Gao, S., Kirchstetter, T. W., Novakov, T., and Pilewskie, P.: Evolution of gases and particles from a savanna fire in South Africa, J. Geophys. Res., 108, 8487, doi:10.1029/2002JD002352, 2003.

Jost, C., Trentmann, J., Sprung, D., Andreae, M. O., McQuaid, J. B., and Barjat, H.: Trace gas chemistry in a young biomass burning plume over Namibia: Observations and model simulations, J. Geophys. Res., 108, 8482, doi:10.1029/2002JD002431, 2003.

Kleiner, I., Tarrago, G., Cottaz, C., Sagui, L., Brown, L. R., Poynter, R. L., Pickett, H. M., Chen, P., Pearson, J. C., Sams, R. L., Blake, G. A., Matsuura, S., Nemtchinov, V., Varanasi, P., Fusina, L., and Di Lonardo, G.: $\mathrm{NH}_{3}$ and $\mathrm{PH}_{3}$ line parameters: the $2000 \mathrm{HI}-$ TRAN update and new results, J. Quant. Spectrosc. Rad. Transfer, 82, 293-312, 2003.

Livesey, N. J., Fromm, M. D., Waters, J. W., Manney, G. L., Santee, M. L., and Read, W. G.: Enhancements in lower stratospheric $\mathrm{CH}_{3} \mathrm{CN}$ observed by the upper atmosphere research satellite microwave limb sounder following boreal forest fires, J. Geophys. Res., 109, D06308, doi:10.1029/2003JD004055, 2004.

Mason, S. A., Trentmann, J., Winterrath, T., Yokelson, R. J., Christian, T. J., Carlson, L. J., Warner, T. R., Wolfe, L. C., and Andreae, M. O.: Intercomparison of two box models of the chemical evolution in biomass-burning smoke plumes, J. Atmos. Chem., 55, 273-297, 2006.

Mauzerall, D. L., Logan, J. A., Jacob, D. J., Anderson, B. E., Blake, D. R., Bradshaw, J. D., Heikes, B., Sachse, G. W., Singh, H., and Talbot, B.: Photochemistry in biomass burning plumes and implications for tropospheric ozone over the tropical South Atlantic, J. Geophys. Res., 103, 19281-19 282, 1998.

Perrin, A., Valentin, A., and Daumont, L.: New analysis of the $2 v_{4}$, $v_{4}+v_{6}, 2 v_{6}, v_{3}+v_{4}, v_{3}+v_{6}, v_{1}, v_{5}, v_{2}+v_{4}, 2 v_{3}, v_{2}+v_{6}$ and $v_{2}+$ $\nu_{3}$, bands of formaldehyde $\left(\mathrm{H}_{2} \mathrm{CO}\right)-{ }^{12} \mathrm{C}^{16} \mathrm{O}$ : Line positions and intensities in the $3.5 \mu \mathrm{m}$ spectral region, Journal of Molecular Structure, 780-81, 28-44, 2006.

Remedios, J. J., Allen, G., and Waterfall, A. M.: Infra-red remote sensing of organic compounds in the upper troposphere, paper presented at ESA Atmospheric Science Conference, ESRIN, Frascati, Italy, 2006.

Remedios, J. J., Allen, G., Waterfall, A. M., Oelhaf, H., Kleinert, A., and Moore, D. P.: Detection of organic compound signatures 
in infra-red, limb emission spectra observed by the MIPAS-B2 balloon instrument, Atm. Chem. Phys., 7, 1599-1613, 2007.

Rinsland, C. P., Boone, C. D., Bernath, P. F., Mahieu, E., Zander, R., Dufour, G., Clerbaux, C., Turquety, S., Chiou, L., McConnell, J. C., Neary, L., and Kaminski, J. W.: First space-based observations of formic acid ( $\mathrm{HCOOH})$ : Atmospheric Chemistry Experiment austral spring 2004 and 2005 Southern Hemisphere tropical-mid-latitude upper tropospheric measurements, Geophys. Res. Lett., 33, L23804, doi:23810.21029/22006GL027128, 2006.

Rinsland, C. P., Coheur, P. F., Herbin, H., Clerbaux, C., Boone, C. D., Bernath, P. F., and Chiou, L.: Detection of elevated tropospheric $\mathrm{H}_{2} \mathrm{O}_{2}$ (hydrogen peroxide) mixing ratios in ACE (atmospheric chemistry experiment) subtropical infrared solar occultation spectra, J. Quant. Spectrosc. Rad. Transfer, 107(2), 340-348, 2007.

Rinsland, C. P., Paton-Walsh, C., Jones, N. B., Griffith, D. W. T., Goldman, A., Wood, S. W., Chiou, L., and Meier, A.: High spectral resolution solar absorption measurements of ethylene $\left(\mathrm{C}_{2} \mathrm{H}_{4}\right)$ in a forest fire smoke plume using HITRAN parameters: Tropospheric vertical profile retrieval, J. Quant. Spectrosc. Rad. Transfer, 96, 301-309, 2005.

Rothman, L. S., Jacquemart, D., Barbe, A., Benner, D. C., Birk, M., Brown, L. R., Carleer, M. R., Chackerian, C., Chance, K., Coudert, L. H., Dana, V., Devi, V. M., Flaud, J. M., Gamache, R. R., Goldman, A., Hartmann, J. M., Jucks, K. W., Maki, A. G., Mandin, J. Y., Massie, S. T., Orphal, J., Perrin, A., Rinsland, C. P., Smith, M. A. H., Tennyson, J., Tolchenov, R. N., Toth, R. A., Vander Auwera, J., Varanasi, P., and Wagner, G.: The HITRAN 2004 molecular spectroscopic database, J. Quant. Spectrosc. Rad. Transfer, 96, 139-204, 2005.

Rusinek, E., Fichoux, H., Khelkhal, M., Herlemont, F., Legrand, J., and Fayt, A.: Subdoppler study of the $v_{7}$ band of $\mathrm{C}_{2} \mathrm{H}_{4}$ with a $\mathrm{CO}_{2}$ laser sideband spectrometer, J. Mol. Spec., 189, 64-73, 1998.

Sadourny, R. and Laval, K.: January and July performance of the LMD general circulation model, in: New Perspectives in Climate Modeling, edited by: Berger, A. L. and Nicolis, C., 173-197, Elsevier, Amsterdam, 1984.
Sharpe, S. W., Johnson, T. J., Sams, R. L., Chu, P. M., Rhoderick, G. C., and Johnson, P. A.: Gas-phase databases for quantitative infrared spectroscopy, Appl. Spectrosc., 58, 1452-1461, 2004.

Trentmann, J., Yokelson, R. J., Hobbs, P. V., Winterrath, T., Christian, T. J., Andreae, M. O., and Mason, S. A.: An analysis of the chemical processes in the smoke plume from a savanna fire, J. Geophys. Res., 110, D12301, doi:10.1029/2004JD005628, 2005. van der Werf, G. R., Randerson, J. T., Giglio, L., Collatz, G. J., Kasibhatla, P. S., and Arellano, A. F.: Interannual variability in global biomass burning emissions from 1997 to 2004, Atmos. Chem. Phys., 6, 3423-3441, 2006,

http://www.atmos-chem-phys.net/6/3423/2006/.

Waters, J. W., Froidevaux, L., Harwood, R. S., Jarnot, R. F., Pickett, H. M., Read, W. G., Siegel, P. H., Cofield, R. E., Filipiak, M. J., Flower, D. A., Holden, J. R., Lau, G. K., Livesey, N. J., Manney, G. L., Pumphrey, H. C., Santee, M. L., Wu, D. L., Cuddy, D. T., Lay, R. R., Loo, M. S., Perun, V. S., Schwartz, M. J., Stek, P. C., Thurstans, R. P., Boyles, M. A., Chandra, K. M., Chavez, M. C., Chen, G. S., Chudasama, B. V., Dodge, R., Fuller, R. A., Girard, M. A., Jiang, J. H., Jiang, Y. B., Knosp, B. W., LaBelle, R. C., Lam, J. C., Lee, K. A., Miller, D., Oswald, J. E., Patel, N. C., Pukala, D. M., Quintero, O., Scaff, D. M., Van Snyder, W., Tope, M. C., Wagner, P. A., and Walch, M. J.: The Earth Observing System Microwave Limb Sounder (EOS MLS) on the Aura satellite, Ieee Transactions on Geoscience and Remote Sensing, 44, 1075-1092, 2006.

Wittrock, F., Richter, A., Oetjen, H., Burrows, J. P., Kanakidou, M., Myriokefalitakis, S., Volkamer, R., Beirle, S., Platt, U., and Wagner, T.: Simultaneous global observations of glyoxal and formaldehyde from space, Geophys. Res. Lett., 33, L16804, doi:10.1029/2006GL026310, 2006.

Yokelson, R. J., Bertschi, I. T., Christian, T. J., Hobbs, P. V., Ward, D. E., and Hao, W. M.: Trace gas measurements in nascent, aged, and cloud-processed smoke from African savanna fires by airborne Fourier transform infrared spectroscopy (AFTIR), J. Geophys. Res., 108, 8478, doi:10.1029/2002JD002322, 2003. 